\title{
Isolation of Endophytic Bacteria from Palm Oil Fruits and Characterization of Their Lipases
}

\author{
FANDY DJAFAR $^{1}$, TRESNAWATI PURWADARIA $^{2 *}$, AND ARNOLD PARLINDUNGAN SINURAT ${ }^{2}$ \\ ${ }^{I}$ Faculty of Biotechnology, Universitas Katolik Indonesia Atma Jaya, \\ Jalan Jenderal Sudirman 51, Jakarta 12930, Indonesia \\ ${ }^{2}$ Indonesian Research Institute for Animal Production, Departemen Pertanian, \\ POBox 221, Bogor 16002, Indonesia
}

\begin{abstract}
Lipases (EC 3.1.1.3) can be produced in palm oil fruits by fruit cells or endophytic microbes. The purpose of this research is to isolate endophytic lipolytic bacteria of palm oil fruit and characterization their lipases. The bacteria were isolated and screened using medium Kouker and Jaeger containing olive oil, minerals, yeast extract, peptone, agar, and rhodamine B as an indicator. Fifteen endophytic bacteria were isolated and identified having the microbial lipase activity. Most of them showed rod shape, positively Gram test, spore formation, and motility except one bacteria strain $\mathrm{K}$ which was coccus. The enzyme was produced using submerged culture in the same medium but not containing agar and rhodamine B. Based on data of enzyme activity towards p-nitrophenyl palmitate as a substrate, protein concentration, and specific activity, two bacteria were selected, those were BSWt2(1) and Ink 1.3 isolates. Microscopic and biochemistry analyses show that BSWt2(1) and Ink 1.3 were identified as Bacillus brevis and B. lacterosporus respectively. Crude lipase from B. brevis BSWt2(1) and B. lacterosporus Ink 1.3 showed optimum activities at $\mathrm{pH} 8.0-9.0$ and $60^{\circ} \mathrm{C}$, and at $\mathrm{pH} 8.5$ and $60-70^{\circ} \mathrm{C}$. The enzymes were stable preincubated at $\mathrm{pH} 7.5-9.0$ and $\mathrm{pH} 7.5-8.0$ respectively, and they were stable pre-incubated for $2-4$ hours at $80^{\circ} \mathrm{C}$ and for $2-8$ hours at $100^{\circ} \mathrm{C}$. Based on stability in high temperature, lipase from both isolates were specific and might be applicable for use in waste water treatment in palm oil factories.
\end{abstract}

Key words: palm oil-fruits, endophytic bacteria, lipase-activity

Lipase (triacylglycerol acylhydrolase, EC 3.1.1.3) is a carboxyesterase that hydrolyzes and synthesizes acylglycerol chains (Jaeger et al. 1999). The hydrolysis reaction degrades the triglyceride to diglyceride, monoglyceride, glycerol, and free fatty acid (John and Abraham 1991). The lipase often shows positional specificity attacking the glycerol side of the triglycerides, 1 or 3 carbon positioned of glycerol molecules are preferable. The hydrolysis of 2-fatty acid monoglyceride occurs after lipase attacks the glyceride at the 1 and /or the 3 position (Saxena et al. 1999) and the 2 acyl moiety migrates to the 1 or 3 position of the glycerol molecule. The hydrolysis reactions occur when lipase meet a substrate a high water content, while in organic solvent conditions trans- and interesterification reactions occur.

Lipase is produced by bacteria, fungi, animals, plants, and humans. Lipase in palm oil fruits can be produced by endogeneous microbes including endophytic bacteria. The association between the endophytic bacteria and palm oil may be pathogenic, commensal, or mutual symbiosis. The presence of endophytic bacteria in fruit palm oil tissue produce fatty acids and compounds for the germination process. The fatty acids are extracted in crude palm oil, thus reducing the oil quality (Strobel 2002). Therefore, endophytic bacteria of palm oil fruit may contain a novel bacterium that is useful for lipase production in the biotechnological industry (Strobel and Daisy 2003).

Many kinds of bacteria produce lipase like Bacillus megaterium, B. stearotermophilus, Serratia marcescens, Aeromonas sp., Pseudomonas sp., Acinetobacter sp., Geobacillus thermoleovorans, and Vibrio fischeri. The enzymes have been well characterized such as their optimum

*Corresponding author, Phone: $+62-251-8240752 / 3$; Fax: +62-251-8240754; Email: tpurwadaria@yahoo.co.uk
$\mathrm{pH}$ and temperature, as well as their molecular weight ( $\mathrm{Li}$ et al. 1995; Lin et al. 1996; Pencreac'h and Baratti 1996; Sharma et al. 2001; Snellman et al. 2002; Abdou 2003; Lee et al. 2003; Oh et al. 2003; Quintana-Castro et al. 2009; Ranjitha et al. 2009). Lipolytic molds were observed on Aspergillus oryzae and Rhizopus oryzae, while Candida rugrosa and C. antartica were lipolytic yeasts (Toida et al. 1995, Benjamin and Pandey 1996, Kose et al. 2002, Shiraga et al. 2005).

Lipase potentially hydrolyzes palm oil into flavouring compounds and could be used to produce biodiesel by interesterification reactions. In palm oil industries, lipase is well known as a biocatalyst in oil extraction and waste treatment (Wenten 2004). The addition of lipase will enhance the metabolisable energy of feed ingredients with high lipid content such as palm kernel meal, palm oil sludge, or crude palm oil. Lipase will be very useful for digesting oil pollutant in waste water management of palm oil or coconut oil factories. The application of lipase in feed and waste management system will be more effective if the microenvironment condition is suitable for the enzyme characteristic including the optimum $\mathrm{pH}$ and temperature, as well as $\mathrm{pH}$ and temperature stabilities. Therefore research was carried out to isolate and screen the lypolytic endophytic bacteria from palm oil fruits and to identify and to determine the characteristics of the enzymes produced by the bacteria.

\section{MATERIALS AND METHODS}

Isolation and Screening of Lipolytic Bacteria. Endophytic bacteria were isolated from palm oil fruits obtained from PT Agricinal, Bengkulu. The medium used for isolation and screening contains $2.5 \%$ olive oil (w/v); $0.2 \%$ glycerol (w/v); $0.002 \%$ rhodamine B (w/v), Merck; $1.5 \%$ peptone (w/v); $0.2 \% \mathrm{KH}_{2} \mathrm{PO}_{4}(\mathrm{w} / \mathrm{v}) ; 0.01 \% \mathrm{MgSO}_{4} \cdot 7 \mathrm{H}_{2} \mathrm{O}$ $(\mathrm{w} / \mathrm{v}) ; 0.5 \% \mathrm{NaCl}(\mathrm{w} / \mathrm{v}) ; 0.01 \%$ biotin $(\mathrm{w} / \mathrm{v}) ; 0.5 \%$ yeast 
extract (w/v); $0.2 \%$ beef extract (w/v); and 3.0\% agar (w/v). The media were adjusted to $\mathrm{pH} 7.2$ with $\mathrm{NaOH} 0.1 \mathrm{M}$ (Kouker and Jaeger 1987). Isolation of endophytic bacteria was carried out according to Coombs and Franco (2003) using to sterilize the surface of palm oil fruits for $5 \mathrm{~min}$. The sterilized fruits were peeled and the mesocarp was aseptically transferred to a mortar to which was added $0.85 \%$ $\mathrm{NaCl}$. The extract $(100 \mu \mathrm{L})$ of the crushed fruit was incorporated in $10 \mathrm{~mL}$ peptone water containing $1.0 \%$ peptone (w/v), $0.5 \% \mathrm{NaCl}(\mathrm{w} / \mathrm{v})$, a

Production of Lipase. The production medium composition was similar with the screen medium but not excluding rhodamine B and agar. One percent of inoculum was added to an aliquat of production medium and incubated at $37^{\circ} \mathrm{C}, 150 \mathrm{rpm}$ for $48 \mathrm{~h}$. After that, $0.2 \% \mathrm{NaN}_{3}$ was added to the culture to eliminate the isolate. The cell free supernatant containing the crude extracellular enzyme was collected after centrifuging the culture at $12000 \times \mathrm{g}, 4^{\circ} \mathrm{C}$ for $30 \mathrm{~min}$. The crude enzyme was kept in $4^{\circ} \mathrm{C}$ refrigerator for further analyses.

Enzyme Assay and Protein Concentration. Lipase activity was determined by using p-nitrophenyl palmitate (pNPP) (Sigma) as a substrate (Snellman et al. 2002). The assay was carried out according to modification of Pencreac'h and Baratti (1996). Substrate was prepared by mixing 1 vol of freshly $16.5 \mathrm{mM}$ pNPP in 2-propanol with 9 vol buffer $\mathrm{pH} 7.0$ containing $0.4 \%$ triton X100. Incubation was carried out at $45^{\circ} \mathrm{C}$ for $30 \mathrm{~min} . \mathrm{Na}_{2} \mathrm{CO}_{3}$ was replaced with $500 \mu \mathrm{L}$ TCA $0.1 \mathrm{M}$ to stop the reaction. One nKat of enzyme was defined as the amount of lipase which liberates 1 nanomol of $\mathrm{p}$-Nitrophenol ( $\mathrm{pNP}$ ) per second under the given assay conditions. The activity of lipase was determined by subtracting the pNP concentration of the sample and the control. All assays were conducted in triplicate, the mixture of buffer and substrate was used as a blank. Specific activities (nKat $\mathrm{mg}^{-1}$ ) were determined using the amount of enzyme protein (mg), as quantified by using coomasie blue solution with bovine serum albumin as a standard (Bradford 1976).

Statistical Analysis. Analysis of variance in lipase production was performed by completely randomized design for fifteen kinds of lipolytic bacteria and every treatment was repeated three times. Significant difference between treatments was carried out by Duncan analysis.

Identification of the Best Isolate. Based on three variables, i.e., lipase activity (nKat $\mathrm{mL}^{-1}$ ), protein concentration $\left(\mu \mathrm{g} \mathrm{mL}^{-1}\right)$, and specific activity (nKat $\mathrm{mg}^{-1}$ ), two isolates were selected and identified. The identification was carried out in School of Life Science and Technology, Institut Teknologi Bandung.
Optimum pH and Temperature. The effect of $\mathrm{pH}$ difference on $\mathrm{pNPP}$ hydrolysis was measured over a $\mathrm{pH}$ range from 6.0 to 9.0 by using Mc. Ilvaine buffer $0.1 \mathrm{M}(\mathrm{pH}$ 6.0-7.5), $\mathrm{K}_{2} \mathrm{HPO}_{4}$ buffer $0.1 \mathrm{M}$ (pH 7.5-8.0), and Tris-Cl buffer $0.1 \mathrm{M}$ (pH 8.0-9.0) under standard enzyme assay conditions. The optimum temperature was determined by performing the standard assay at temperatures ranging from 40 to $80^{\circ} \mathrm{C}$ at optimum $\mathrm{pH}$.

pH and Temperature Stability. The effect of $\mathrm{pH}$ on the stability of assayable lipase activity was determined by using the same buffers in the range of $\mathrm{pH} 6.5$ to $\mathrm{pH} 9.0$. After preincubation for $30 \mathrm{~min}$ at each $\mathrm{pH}$ at $25^{\circ} \mathrm{C}$, the enzyme activity was determined under optimum assay conditions, at $\mathrm{pH} 8.0$ and at $60^{\circ} \mathrm{C}$ and $70^{\circ} \mathrm{C}$ respectively for two selected isolates. Thermal stability was determined by assaying the lipase activity after pre-incubation of the enzyme at $\mathrm{pH}$ optimum at 80 and $100^{\circ} \mathrm{C}$ for $0,2,4$, and $8 \mathrm{~h}$. Following incubation, the enzyme activity was determined by assay under optimal $\mathrm{pH}$ and temperature.

\section{RESULTS}

All bacteria isolated from palm oil fruits were screened for lipolytic activity. Fifteen isolates grew well on screen medium at $37^{\circ} \mathrm{C}$ and showed good lipolytic activity, but they did not grow at $50^{\circ} \mathrm{C}$ (data were not shown). All isolates showed similar microscopic characteristics such as bacil, Gram positive, and spore forming, except that of $\mathrm{K}$ isolate was coccus, Gram positive and non-spore forming (Table 1). All bacils were motile, while the coccus was non-motile.

The fifteen isolates had highly significantly different activity $(\mathrm{P}<0.0005)$ (Table 2$)$. BSWt 2(1), Ink 1.3, and Ink 1.10 isolates produced the highest assayable activity among

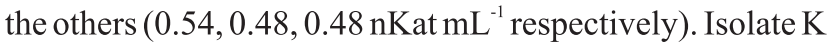
produced the highest protein concentration $296 \mu \mathrm{g} \mathrm{mL}^{-1}$.

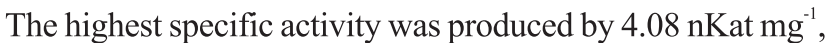
however, it had significantly lower activity than those from

Table 1 Characterization of endophytic and lipolytic bacteria isolated from palm oil fruit

\begin{tabular}{llccc}
\hline Isolates & Morphology & $\begin{array}{c}\text { Gram } \\
\text { staining }\end{array}$ & Spore & $\begin{array}{c}\text { Motility } \\
\text { test }\end{array}$ \\
\hline BSWt 2(1) & Streptobacil & + & + & Motile \\
B.A & Streptobacil & + & + & Motile \\
K & Staphylococcus & + & - & Non-motile \\
Ink 1.a & Streptobacil & + & + & Motile \\
Ink 1.c & Bacil & + & + & Motile \\
Ink 1.3 & Duplobacil & + & + & Motile \\
Ink 1.4 & Bacil & + & + & Motile \\
Ink 1.5 & Streptobacil & + & + & Motile \\
Ink 1.6 & Bacil & + & + & Motile \\
Ink 1.9 & Bacil & + & + & Motile \\
Ink 1.10 & Duplobacil & + & + & Motile \\
Ink 1.11 & Bacil & + & + & Motile \\
Ink 1.12 & Streptobacil & + & + & Motile \\
Ink 2.2 & Streptobacil & + & + & Motile \\
Ink 2.6 & Streptobacil & + & + & Motile \\
\hline
\end{tabular}


Table 2 Activity, protein concentration, and specific activity of enzyme produced by bacterial isolates

\begin{tabular}{|c|c|c|c|}
\hline Isolates & $\begin{array}{l}\text { Activity } \\
\left(\mathrm{nKat} \mathrm{mL}^{-1}\right)\end{array}$ & $\begin{array}{l}\text { Protein } \\
\left(\mu \mathrm{g} \mathrm{mL} L^{-1}\right)\end{array}$ & $\begin{array}{l}\text { Specific activity } \\
\left(\mathrm{nKat} \mathrm{mg}^{-1}\right)\end{array}$ \\
\hline BSWt 2(1) & $0.54^{\mathrm{a}}$ & $225^{\mathrm{abc}}$ & $2.44^{\text {bcde }}$ \\
\hline B.A & $0.17^{\mathrm{de}}$ & $142^{\operatorname{defg}}$ & $1.24^{\mathrm{ef}}$ \\
\hline $\mathrm{K}$ & $0.29^{\mathrm{bc}}$ & $296^{\mathrm{a}}$ & $0.98^{\text {ef }}$ \\
\hline Ink 1.a & $0.16^{\mathrm{e}}$ & $104^{\text {fghi }}$ & $1.57^{\text {cdef }}$ \\
\hline Ink 1.c & $0.23^{\text {cde }}$ & $64^{\mathrm{hi}}$ & $4.08^{\mathrm{a}}$ \\
\hline Ink 1.3 & $0.48^{\mathrm{a}}$ & $173^{\text {cdef }}$ & $3.11^{\mathrm{abc}}$ \\
\hline Ink 1.4 & $0.16^{\text {ed }}$ & $228^{\mathrm{abc}}$ & $0.72^{\mathrm{f}}$ \\
\hline Ink 1.5 & $0.29^{\mathrm{bc}}$ & $188^{\text {bcde }}$ & $1.57^{\text {cdef }}$ \\
\hline Ink 1.6 & $0.17^{\mathrm{ed}}$ & $116^{\text {efghi }}$ & $1.47^{\text {cdef }}$ \\
\hline Ink 1.9 & $0.35^{\mathrm{b}}$ & $252^{\mathrm{ab}}$ & $1.50^{\text {cdef }}$ \\
\hline Ink 1.10 & $0.48^{\mathrm{a}}$ & $198^{\text {bcd }}$ & $2.93^{\mathrm{abcd}}$ \\
\hline Ink 1.11 & $0.26^{\text {bcd }}$ & $199^{\text {bcd }}$ & $1.34^{\mathrm{def}}$ \\
\hline Ink 1.12 & $0.20^{\mathrm{ed}}$ & $85^{\text {ghi }}$ & $2.30^{\text {bcdef }}$ \\
\hline Ink 2.2 & $0.16^{\text {ed }}$ & $50^{\mathrm{i}}$ & $3.45^{\mathrm{ab}}$ \\
\hline Ink 2.6 & $0.16^{\mathrm{ed}}$ & $127^{\text {defgh }}$ & $1.29^{\mathrm{def}}$ \\
\hline
\end{tabular}

Different superscript characters in the same column shows highly significant difference $(\mathrm{P}<0.0005)$.

Table 3 Characterization of BSWt 2(1) and Ink 1.3 isolates*

\begin{tabular}{|c|c|c|}
\hline \multirow{2}{*}{ Characteristic } & \multicolumn{2}{|c|}{ Isolate } \\
\hline & BSWt 2(1) & Ink 1.3 \\
\hline \multicolumn{3}{|l|}{ Macroscopic } \\
\hline Colony edge & Undulate & Lobate \\
\hline Colony opacity & Opaque & Opaque \\
\hline Microscopic & Bacil & Bacil \\
\hline Spore formation & $\begin{array}{l}\text { Ellips and } \\
\text { subterminal }\end{array}$ & $\begin{array}{l}\text { Ellips and } \\
\text { central }\end{array}$ \\
\hline Motility & Motile & Motile \\
\hline \multicolumn{3}{|l|}{ Bio-chemical test: } \\
\hline Protease & + & + \\
\hline Amylase & - & - \\
\hline Lipase (Tributirin) & ++ & -+ \\
\hline Gelatinase & + & + \\
\hline Nitrate reduction & + & + \\
\hline Methyl red & + & + \\
\hline Voges-Proskauer & - & - \\
\hline Urease & - & - \\
\hline Indole reaction & - & + \\
\hline $\mathrm{H}_{2} \mathrm{~S}$ production & - & - \\
\hline Catalase & + & + \\
\hline Growth on citrate & - & - \\
\hline Glucose fermentation & -+ & + \\
\hline Sucrose fermentation & + & + \\
\hline Lactose fermentation & - & - \\
\hline Triple s ugar iron agar & + & + \\
\hline Conclusion & Bacillus brevis & Bacillus laterosporus \\
\hline
\end{tabular}

*Identification was held at Laboratory of Microbiology, School of Biological Science and Technology, Institut Teknologi Bandung. + was positive; - , negative; -+ , weakly positive; ++ , very strongly positive.

BSWt 2(1) and Ink 1.3. The crude enzymes of the two isolates were selected for feed application. High assayable activity of crude enzymes was more useful than their specific activity. Specific activity was more important, if the enzyme would be purified for enzyme characterization. BSWt 2(1) was chosen for further experiment for high assayable activity and protein concentration, but moderate specific activity, while Ink 1.3 was chosen for high assayable activity and specific activity, but moderate protein concentration. Identification on the macroscopic observation and biochemistry test for BSWt 2(1) and Ink 1.3. showed that both isolates were Bacillus brevis BSWt 2(1) and B. laterosporus Ink 1.3 (Table 3).

Enzyme produced by B. brevis BSWt 2(1) was most active at $\mathrm{pH} 8.0-9.0$, while that of $B$. laterosporus Ink 1.3 at pH 8.5 (Fig 1). The measurement of enzyme activity at higher than $\mathrm{pH} 9.0$ was discontinued, because $\mathrm{pH}$ higher than 9.0 (9.5) resulted saponification reaction in pNPP that increases the assayable activity. Optimum temperature at phosphate buffer $\mathrm{pH} 8.0$ of lipase produced by B. brevis BSWt 2(1) was observed at $60^{\circ} \mathrm{C}$, and the activity sharply decreased at $70^{\circ} \mathrm{C}$. The optimum temperature for lipase activity produced by $B$. laterosporus Ink 1.3 at Tris-buffer $\mathrm{pH} 8.5$ was at $60-70^{\circ} \mathrm{C}$ and the activity sharply decreased at $80^{\circ} \mathrm{C}$.

The $\mathrm{pH}$ stability was observed by the relative activity of lipase pre-incubated for $30 \mathrm{~min}$ at different $\mathrm{pH}$ towards activity without incubation. The lipases produced by $B$. brevis BSWt 2(1) and B. laterosporus Ink 1.3 were more
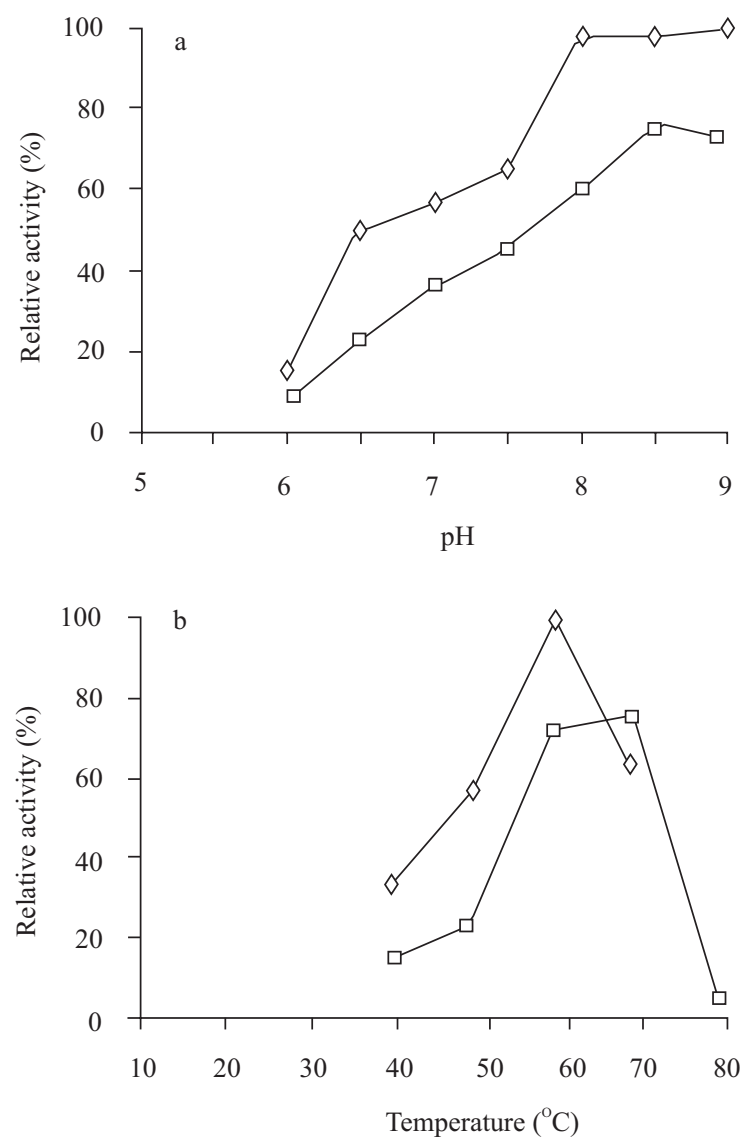

Fig 1 Optimum $\mathrm{pH}$ (a) and temperature (b) of lipases produced by Bacillus brevis BSWt 2(1) $(\diamond)$ and B. laterosporus Ink 1.3 (口). Buffers used were Mc Ilvaine ( $\mathrm{pH}$ 6.0-7.5), phosphate ( $\mathrm{pH} 7.5-8.0)$, and Tris-Cl (pH $8.0-9.0)$. 
Table 4 The effect of $\mathrm{pH}$ pre-incubation on lipase specific activity of Bacillus brevis BSWt 2(1) and B. laterosporus Ink 1.3

\begin{tabular}{|c|c|c|c|c|c|}
\hline \multirow[b]{2}{*}{ Lipase } & \multirow{2}{*}{$\begin{array}{l}\text { Kind of } \\
\text { buffers }\end{array}$} & \multirow[b]{2}{*}{$\mathrm{pH}$} & \multicolumn{2}{|c|}{$\begin{array}{l}\text { Preincubation } \\
\text { (min) }\end{array}$} & \multirow{2}{*}{$\begin{array}{l}\text { Relative } \\
\text { specific } \\
\text { activity } \\
\text { (times)* }\end{array}$} \\
\hline & & & $\begin{array}{l}0 \\
(\mathrm{nK}\end{array}$ & $\begin{array}{c}30 \\
\left.g^{-1}\right)\end{array}$ & \\
\hline \multirow[t]{8}{*}{ B. brevis BSWt 2(1) } & \multirow[t]{3}{*}{ Mc. Ilvaine } & 6.5 & 0.99 & 0.66 & 0.66 \\
\hline & & 7.0 & 3.34 & 2.36 & 0.70 \\
\hline & & 7.5 & 4.99 & 4.74 & 0.95 \\
\hline & \multirow[t]{2}{*}{ Phosphate } & 7.5 & 2.89 & 2.65 & 0.92 \\
\hline & & 8.0 & 4.25 & 3.94 & 0.93 \\
\hline & \multirow[t]{3}{*}{ Tris-Cl } & 8.0 & 1.28 & 1.62 & 1.27 \\
\hline & & 8.5 & 2.26 & 2.55 & 1.13 \\
\hline & & 9.0 & 2.93 & 3.28 & 1.12 \\
\hline \multirow[t]{8}{*}{ B. laterosporus Ink 1.3} & \multirow[t]{3}{*}{ Mc Ilvaine } & 6.5 & 1.13 & 0.86 & 0.76 \\
\hline & & 7.0 & 2.55 & 2.12 & 0.83 \\
\hline & & 7.5 & 5.33 & 4.00 & 0.75 \\
\hline & \multirow[t]{2}{*}{ Phosphate } & 7.5 & 3.89 & 4.17 & 1.08 \\
\hline & & 8.0 & 4.43 & 4.80 & 1.08 \\
\hline & \multirow[t]{3}{*}{ Tris-Cl } & 8.0 & 2.17 & 0.90 & 0.42 \\
\hline & & 8.5 & 2.16 & 0.89 & 0.41 \\
\hline & & 9.0 & 5.15 & 1.92 & 0.37 \\
\hline
\end{tabular}

*The comparison of specific activity at 30 min towards 0 min preincubation time.

stable at $\mathrm{pH} 7.5-9.0$ and at $\mathrm{pH}$ 7.5-8.0 respectively (Table 4). Although assayable temperature lipase from $B$. brevis BSWt $2(1)$ and $B$. laterosporus Ink 1.3 were decreasing at 70 and $80^{\circ} \mathrm{C}$ respectively (Fig 1 ), temperature pre-incubation at $80^{\circ} \mathrm{C}$ for $4 \mathrm{~h}$ and $100^{\circ} \mathrm{C}$ for $8 \mathrm{~h}$ did not reduce assayable activity without pre-incubation at optimum $\mathrm{pH}$ and temperature ( $\mathrm{pH} 8.0$ and $60^{\circ} \mathrm{C}$ for B. brevis BSWt 2(1), and $\mathrm{pH} 8.5$ and $70^{\circ} \mathrm{C}$ for $B$. laterosporus Ink 1.3). Higher pre-incubation temperature resulted higher assayable activity. Lipase produced by B. brevis BSWt 2(1) was more stable to high pre-incubation

\section{DISCUSSION}

Endophytic bacteria are known as the bio-prospecting microbes from many aspects (Strobel and Daisy 2003). The advantage of isolation endophytic bacteria from palm oil fruit was to collect isolate producing novel lipase activity. Lipase from these isolates can be used for many purposes like bioremediation process around palm oil plantation and as an animal feed additive.

A medium containing olive oil and fluorescent rhodamine B can be used to detect the microbial lipase. The lipase digests olive oil to produce free fatty acids that form complex molecules with rhodamine B (Kouker and Jaeger 1987; Olivia et al. 1998). The complex molecules were appeared as an orange fluorescence colony. Two days incubation time is the optimum time to screen highly
Table 5 The effect of temperature pre-incubation at 80 and $100^{\circ} \mathrm{C}$ on lipase specific activity of Bacillus brevis BSWt 2(1) and B. laterosporus Ink 1.3

\begin{tabular}{|c|c|c|c|c|}
\hline \multirow[b]{2}{*}{ Lipase } & \multicolumn{2}{|c|}{ Pre-incubation } & \multirow[b]{2}{*}{$\begin{array}{c}\text { Specific } \\
\text { activity } \\
\left(\mathrm{nKat} \mathrm{mg}^{-1}\right)\end{array}$} & \multirow{2}{*}{$\begin{array}{l}\text { Relative } \\
\text { specific } \\
\text { activity } \\
\text { (times)* }\end{array}$} \\
\hline & $\begin{array}{l}\text { aperature } \\
\left({ }^{\circ} \mathrm{C}\right)\end{array}$ & $\begin{array}{l}\text { Time } \\
\text { (h) }\end{array}$ & & \\
\hline \multirow[t]{8}{*}{ B. brevis BSWt 2(1) } & 80 & 0 & 6.33 & 1.00 \\
\hline & & 2 & 6.49 & 1.03 \\
\hline & & 4 & 7.33 & 1.16 \\
\hline & & 8 & 5.69 & 0.90 \\
\hline & 100 & 0 & 4.67 & 1.00 \\
\hline & & 2 & 5.60 & 1.20 \\
\hline & & 4 & 6.09 & 1.30 \\
\hline & & 8 & 5.73 & 1.23 \\
\hline \multirow[t]{8}{*}{ B. laterosporus Ink 1.3} & 80 & 0 & 4.74 & 1.00 \\
\hline & & 2 & 6.30 & 1.33 \\
\hline & & 4 & 5.43 & 1.15 \\
\hline & & 8 & 3.93 & 0.83 \\
\hline & 100 & 0 & 4.74 & 1.00 \\
\hline & & 2 & 7.92 & 1.67 \\
\hline & & 4 & 6.47 & 1.37 \\
\hline & & 8 & 5.66 & 1.20 \\
\hline
\end{tabular}

*The comparison of specific activity at each pre-incubation time towards 0 h incubation.

lipolytic bacteria qualitatively that produce more obvious orange fluorescence around their colonies, while at one day incubation time, the low- and high-lipolytic bacteria showed a similar orange fluorescence. Fifteen endophytic bacteria, which produced lipase-like assayable activity have been isolated and purified. Fourteen isolates were bacils, and one isolate $(\mathrm{K})$ was a staphylococcus (Table 1 ).

This result might indicate that the isolated bacteria may have a similar genus (Bacillus), or species but different strain. According to Carrim et al. (2006) lipolytic endophytic bacteria from the leaf and stem of Jacaranda decurrens includes Corynebacterium aquaticum, C. renale, Pseudomonas stutzeri and Staphylococcus sp. Lipase and endophytic lipolytic activity were detected in the mesocarp of palm fruit during the germination process (Strobel 2002), while the role of endophytic lipolytic bacteria in J. decurrens has not yet been discussed.

The hydrolytic activity of lipase can be measured by a specific substrate such as pNPP. This reaction was terminated by addition of TCA $0.1 \mathrm{M}$. Many workers used $\mathrm{Na}_{2} \mathrm{CO}_{3}$ to stop the reaction. However, the addition of $\mathrm{Na}_{2} \mathrm{CO}_{3}$ results in a saponification reaction that increases the yellow absorbance and which can give a faulty result. Palmitin was chosen from other substrates such as tributirin, stearin or olein, because the highest fatty acid composition in palm oil is palmitate at $43.0 \%$ (Sauvant et al. 2002). This reaction was also affected by high $\mathrm{pH}$ buffer, the saponification reaction between the substrate and buffer (without enzyme addition) occurred at $\mathrm{pH} \geq 9$.

Although the bacteria have similar morphology and Gram stain, their lipase activity was significantly different (Table 2). B. brevis BSWt 2(1) and B. laterosporus Ink 1.3 which had been explained in the result were selected for further experiments. Other strain of B. brevis produced lipase activity was also reviewed by Sharma et al. (2001). The enzymes of our two microbes had different substrate specific activity. Enzyme produced by B. brevis BSWt 2(1) 
showed more lipase activity in tributirin agar than that from B. laterosporus Ink 1.3 (Table 2), while palmitin (pNPP) substrate was more preferred by $B$. laterosporus Ink 1.3 enzyme. The specific activity of enzyme from $B$. laterosporus Ink 1.3 to hydrolize palmitin was higher than that B. laterosporus Ink 1.3 (Table 3). Lipases from different strains have certain substrate specificities have been found in Bacillus sp. BP-7 and B. subtilis BP-7 which have higher hydrolysis activity to methylumbeliferyl (MUF)-butirin than that to MUF-olein, while enzyme from B. subtilis prefers to hydrolize MUF-olein (Prim et al. 2003).

As mentioned in the result enzymes from $B$. brevis BSWt 2(1) and B. laterosporus Ink 1.3 had optimum activity at $\mathrm{pH}$ 8.0-9.0 and 8.5, respectively (Fig 1). Enzyme from B. brevis BSWt 2(1) and B. laterosporus Ink 1.3 were stable at $\mathrm{pH} 7.5$ 9.0 and $\mathrm{pH}$ 7.5-8.0 respectively (Table 4). Lipase from $P$. pseudoalcaligenes had an optimum activity at $\mathrm{pH} 8.0$ and had a broad range $\mathrm{pH}$ stability from $\mathrm{pH}$ 6.0-10.0 (Lin et al. 1996). Enzyme from Candida rugosa had optimum activity at pH 7.0-8.0 (Benjamin and Pandey 2001). Generally like other enzymes from bacteria, our enzymes have optimum activity under alkaline conditions.

Bacillus brevis BSWt 2(1) and B. laterosporus Ink 1.3 lipases have optimum activity at temperatures of $60^{\circ} \mathrm{C}$ and $60-70^{\circ} \mathrm{C}$ respectively and can be called thermophilic (Fig 1). Oh et al. (2003) reported that the optimum lipase activity from $B$. stearothermophilus was at $60-65^{\circ} \mathrm{C}$. This species grows well under thermophilic conditions, therefore it is very possible that its enzyme is also thermophilic. Benjamin and Pandey (2001) reported that the lipase optimum activity from C. rugosa (mesophilic yeast) was $35-40^{\circ} \mathrm{C}$, while lipase from Aspergillus oryzae (mesophilic mold) has optimal at $30^{\circ} \mathrm{C}$ (Toida et al. 1995). In our result B. brevis BSWt 2(1) and $B$. laterosporus Ink 1.3 grew well at $37^{\circ} \mathrm{C}$ (mesophilic) but they did not grow at $50^{\circ} \mathrm{C}$. However, their enzymes have optimum activity at high temperature and are thermophilic. The specificity of the enzymes will be useful for their application in the $60^{\circ} \mathrm{C}$ environment.

The relative activity of enzymes from $B$. brevis BSWt2(1) and B. laterosporus Ink 1.3 was still high, although incubated at 80 and $100^{\circ} \mathrm{C}$ (Table 5). The relative activity of both lipases showed a proportional increase with increased time at two hours incubation. After two hours incubation, relative activity of $B$. laterosporus Ink 1.3 was decreased, while that of $B$. brevis BSWt 2(1) was still increasing. Although enzymes of $B$. brevis BSWt2(1) and $B$. laterosporus Ink 1.3 have optimum temperature at $60^{\circ} \mathrm{C}$ and $60-70^{\circ} \mathrm{C}$ respectively, or the reduction of assayable activity occurrs at $80^{\circ} \mathrm{C}$ (Fig 1), pre-incubation at 80 and $100^{\circ} \mathrm{C}$ did not reduce the relative activity. After pre-incubation at 80 and $100^{\circ} \mathrm{C}$, the enzymes were assayed at their optimum temperature, $\mathrm{pH} 8.0$ and $60^{\circ} \mathrm{C}$ for $B$. brevis $\mathrm{BSWt} 2(1)$ and $\mathrm{pH} 8.5$ and $70^{\circ} \mathrm{C}$ for $B$. laterosporus Ink 1.3. It is difficult to explain why at high temperature incubation $\left(80\right.$ and $\left.100^{\circ} \mathrm{C}\right)$ the enzyme activity was stable, but at high temperature assay reaction the enzyme activities at $80^{\circ} \mathrm{C}$ were lower than those at $60^{\circ} \mathrm{C}$. Possible explanation might be due to the active site conformation of enzyme molecules. High temperature pre-
The pasteurization or even sterilization processes before storage of foods will kill the bacteria, whereas heat resistant lipase previously produced by them will remain active (Anderson 1980). The activity of this lipase might change the quality in fatty foods during prolonged chilled or dehydrated storage. Prim et al. (2003) reported the characterization from other lipases. Lipase from B. subtilis has a good relative activity after fourty days incubation at $4,20,30$, and $45^{\circ} \mathrm{C}$. The temperature stability incubations of $B$. brevis BSWt2(1) and $B$. laterosporus Ink 1.3 were not carried out at those low temperatures, since we intend to apply the enzyme as feed additive and for waste management around palm oil factories. However, incubation at high temperature already proves the stability of the enzyme. According to Liebeton et al. (2001), the stability of lipase was correlated with disulfide bonds. The disulfide bond stabilized the active site conformation of the enzyme to high temperature.

In bioremediation processes, both our lipases can be appropriately used to decrease the glyceride in palm oil waste. Based on the field observation at the palm oil factory, the conditions of the fresh waste from palm oil were $55-80^{\circ} \mathrm{C}$ and $\mathrm{pH}$ 5.0-6.0. The gastroinstestinal $\mathrm{pH}$ from poultry is acid and the body temperature is $40^{\circ} \mathrm{C}$, and the temperature during the pelleting process is $70-85^{\circ} \mathrm{C}$. Based on the characterization results, both lipases had optimum activity at alkaline and thermophilic conditions so were not appropriate as feed supplement, however, pelleting temperature will not reduce the activity of these enzymes. The enzyme will be useful if the hydrolysis is carried out as pre-treatment in the optimum microenvironmental conditions. Thus, the effectiveness from this activity must be correlated with the amount of enzyme added. There was another aspect of lipase activity which was not measured in this experiment, that is the interesterification reaction. The interesterification process was correlated with the biodiesel process. Therefore, more research is suggested to explore the characteristics of both lipases.

Although the application of enzymes produced in this experiment has to be explored. Further results of this study showed that the isolation of endophytic lipolytic bacteria from the mesocarp of palm fruit is important. The isolated bacteria produced specific enzyme activity which is stable at high incubation temperatures.

\section{ACKNOWLEDGEMENT}

We would like to thank Indonesian Research Institute for Animal Production for its financial support in this research. The funding was from the research activity budget in 2005 .

\section{REFERENCES}

Abdou MA. 2003. Purification and partial characterization of psychrotrophic Serratia marcescens lipase. J Dairy Sci 86:127-32.

Anderson RE. 1980. Microbial lipolysis at low temperature. Appl Environ Microbiol 39:36-40.

Benjamin S, Pandey A. 1996. Optimization of liquid media for lipase production by Candida rugrosa. Bioresour Technol 55:167-70. 
Benjamin S, Pandey A. 2001. Isolation and characterization of three distinct forms of lipases from Candida rugosa produced in solid state fermentation. BrazArch Bio Tech 44:213-21.

Bradford MM. 1976. A rapid and sensitive method for the quantitation of microgram quantities of protein utilizing the principle of protein-dye binding. Anal Biochem 72:248-54.

Carrim AJI, Barbosa EC, Vieira JDG. 2006. Enzymatic activity of endophytic bacterial isolates of Jacaranda decurrens Cham (Carobinha-do-campo). BrazArch Bio Technol 49:353-9.

Coombs JT, Franco CMM. 2003. Isolation and identification of Acinetobacteria from surface-sterilized wheat roots. Appl Environ Microbiol 69:5603-8.

Jaeger KE, Djikstra BW, Reetz MT. 1999. Bacterial biocatalysts: molecular biology. three-dimensional structures and biotechnology applications of lipases [review]. Ann Rev Microbiol 53:315-51.

John VT, Abraham G. 1991. Biocatalysts for industry. New York: Plenum Pr.

Kose O, Tuter M, Aksoy HA. 2002. Immobilized Candida antartica lipase-catalyzed alcoholysis of cotton seed oil in a solvent-free medium. Bioresour Technol 83:125-9.

Kouker G, Jaeger KE. 1987. Specific and sensitive plate assay for bacterial lipases. Appl Environ Microbiol 53:211-3.

Lee HK, Min JA, Sung HK, Won HS, Byeong CJ. 2003. Purification and characterization of cold active lipase from psychrotrophic Aeromonas sp. LPB 4. J Microbiol 41:22-7.

Li X, Tetling S, Winkler UK, Jaeger KE, Benedik MJ. 1995. Gene cloning, sequence analysis, purification, and secretion by Escherichia coli of an extracellular lipase from Serratia marcescens. Appl Environ Microbiol 61:2674-80.

Liebeton K, Zacharias A, Jaeger KE. 2001. Disulfide bond in Pseudomonas aeruginosa lipase stabilizes the structure but is not required for interaction with its foldase. J Bacteriol 183:597-603.

Lin SF, Chiou CM, Yeh CM, Tsai YC. 1996. Purification and partial characterization of an alkaline lipase from Pseudomonas pseudoalcaligenes F-11. Appl Environ Microbiol 62:1093-5.

Oh JA, Jang HW, Lee HW, Choi ES, Haam SJ, Oh TK, Jung JK. 2003. Overexpression of thermoalkalophilic lipase from Bacillus stearothermophilus L1 in Saccharomyces cerevisiae. J Microbiol Biotechnol 13:45-6.

Olivia F, Gunawan AW, Suwanto A. 1998. Isolation and detection of lipase from Rhizopus spp [in Indonesian]. [research notes]. Hayati 5:113-5.
Pencreac'h G, Baratti JC. 1996. Hydrolysis of p-nitrophenyl palmitate in nheptane by the Pseudomonas cepacia lipase: a simple test for the determination of lipase activity in organic media. Enzyme Microb Technol 18:417-22

Prim N, Sanchez M, Ruiz C, Pastor J, Diaz P. 2003. Use of methylumbeliferyl-derivative substrates for lipase activity characterization. J Mol Catal 22:339-46.

Quintana-Castro R, Diaz P, Valerio-Alfaro G, Garcia HS, Oliart-Ros R. 2009. Gene cloning, expression, and characterization of the Geobacillus thermoleovorans CCR11 thermoalkaliphilic lipase. Mol Biotechnol 42:75-83.

Ranjitha P, Karthy ES, Mohankumar A. 2009. Purification and characterization of lipase from marine Vibrio fischeri. CCSE Int J Biol 1:48-56.

Sauvant D, Perez JM, Tran G. 2002. Tables of composition and nutritional value of feed materials. Wageningen: Wageningan Academic Publ.

Saxena RK, Ghosh PK, Gupta R, Davidson WS, Bradoo S, Gulati R. 1999. Microbial lipases: potential biocatalysts for the future industry. Curr Sci 77:101-15.

Sharma R, Cristi Y, Banerjee UC. 2001. Production, purification, characterization, and applications of lipases [review]. Biotechnol Adv 19:627-62.

Shiraga S, Kawakami M, Ishiguro M, Ueda M. 2005. Enhanced reactivity of Rhizopus oryzae lipase displayed on yeast cell surfaces in organic solvents:potential as whole-cell biocatalyst in organic solvent. Appl Environ Microbiol 71:4335-8.

Snellman EA, Sullivan ER, Colwell RR. 2002. Purification and properties of the extracellular lipase LipA of Acinetobacter sp. RAG-1. Eur J Biochem 269:5771-9.

Strobel GA. 2002. Microbial gifts from rain forests. Can J Plant Pathol 24:14-20.

Strobel GA, Daisy B. 2003. Bioprospecting for microbial endophytes and their natural products [review]. Microbiol Mol Biol Rev 67:491-502.

Toida J, Kondoh K, Fukuzawa M, Ohnishi K, Sekiguchi J. 1995. Purification and characterization of a lipase from Aspergillus oryzae. Biosci Biotech Biochem 59:1199-203.

Wenten IG. 2004. Zero waste effluent process integrated with animal and palm oil plantation. [in Indonesian] In: Proceedings of animalplantation integration system; 2004 Jul, 20-22; Denpasar, Indonesia. Bogor: ICARD. 